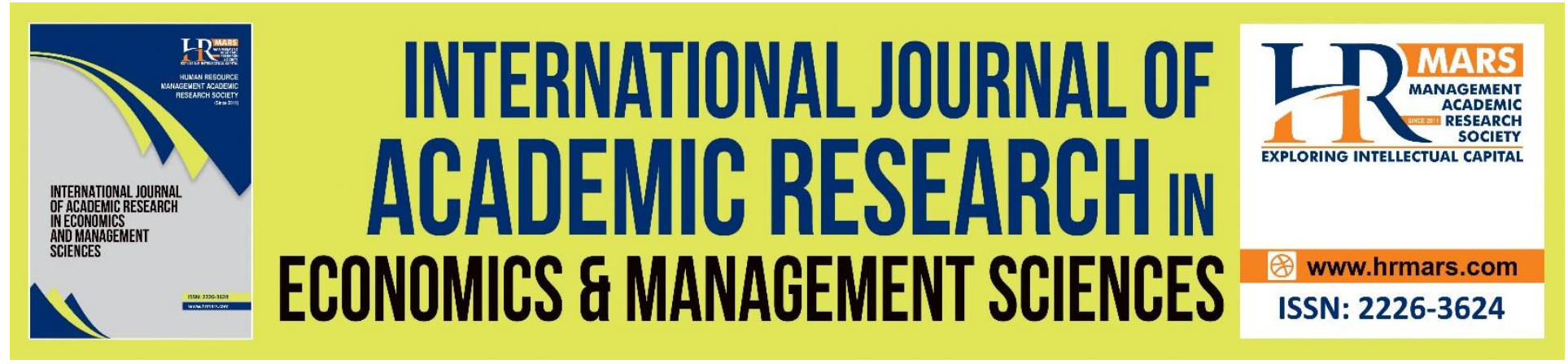

\title{
The Effect of Government Support for Fuel and Wheat on Economic Growth in Jordan: An Application of Dynamic Autoregressive-Distributed Lag
}

Bashar Younis Alkhawaldeh, Suraya Mahmood

To Link this Article: http://dx.doi.org/10.6007/IJAREMS/v10-i1/9179

DOI:10.6007/IJAREMS/v10-i1/9179

Received: 15 January 2021, Revised: 20 February 2021, Accepted: 06 March 2021

Published Online: 30 March 2021

In-Text Citation: (Alkhawaldeh \& Mahmood, 2021)

To Cite this Article: Alkhawaldeh, B. Y., \& Mahmood, S. (2021). The Effect of Government Support for Fuel and Wheat on Economic Growth in Jordan: An Application of Dynamic Autoregressive-Distributed Lag.

International Journal of Academic Research in Economics and Managment and Sciences, 10(1), 108-122.

\section{Copyright: (c) 2021 The Author(s)}

Published by Human Resource Management Academic Research Society (www.hrmars.com)

This article is published under the Creative Commons Attribution (CC BY 4.0) license. Anyone may reproduce, distribute, translate and create derivative works of this article (for both commercial and non-commercial purposes), subject to full attribution to the original publication and authors. The full terms of this license may be seen

at: http://creativecommons.org/licences/by/4.0/legalcode

Vol. 10, No. 1, 2021, Pg. 108 - 122

http://hrmars.com/index.php/pages/detail/IJAREMS

JOURNAL HOMEPAGE

Full Terms \& Conditions of access and use can be found at http://hrmars.com/index.php/pages/detail/publication-ethics 


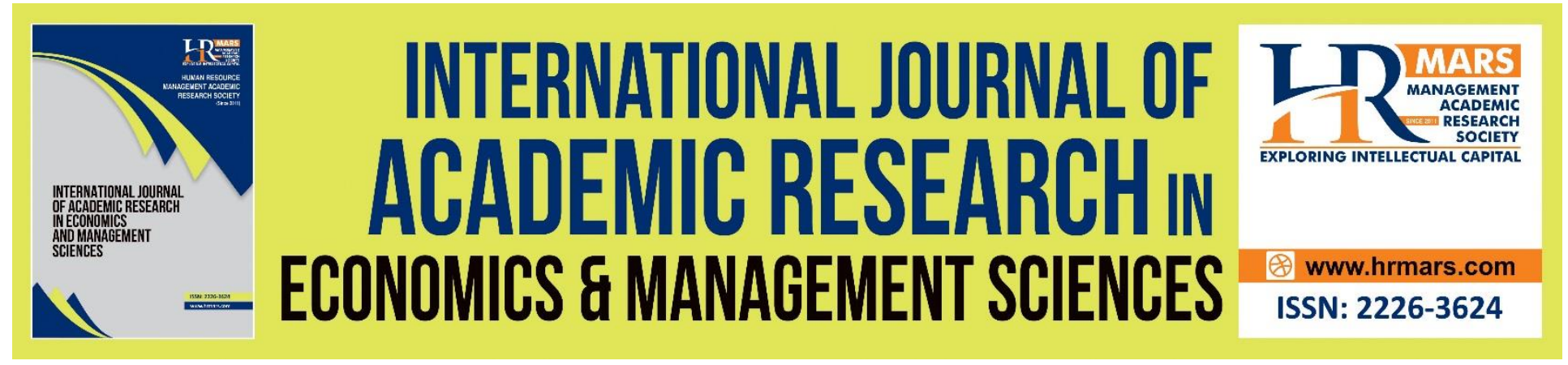

\title{
The Effect of Government Support for Fuel and Wheat on Economic Growth in Jordan: An Application of Dynamic Autoregressive-Distributed Lag
}

\author{
Bashar Younis Alkhawaldeh, Suraya Mahmood \\ Faculty of Business and Management, Universiti Sultan Zainal Abidin, Terengganu, Malaysia \\ Email: basharyounes@yahoo.com,surayamahmood@unisza.edu.my
}

\begin{abstract}
This study aims to investigate the effect of government support for Fuel and Wheat on economic growth in Jordan. This study employs the time series data from 1970-2019. Furthermore, this study applies the powerful unit root to test the stationarity of the variables. The unit root tests are Augmented Dickey-Fuller, Phillips-Perron, Saikonen and Lütkepohl and Zivot-Andrews. Moreover, this study also uses a recent cointegration test developed by Gregory and Hansen to investigate the long-run effect of government support for fuel and Wheat on economic growth. Similarly, this study uses dynamic autoregressive distributive lags. The results of unit root tests show that all the variables are stationary. Also, the results of the cointegration test reveal the long-run effect of government support for fuel and Wheat and trade openness on economic growth in Jordan. Similarly, the long-run and short-run estimates reveal the positive effects of both government support for fuel and Wheat and trade openness on economic growth, respectively. While the 2015 food crisis shows a negative effect on economic growth, conclusively, the policy will be contributed to Jordan to optimize the effects of government support for fuel and Wheat in economic growth. It is also recommended that if government support is utilized in the excess amount, the excessive development support becomes unproductive at the margin. Moreover, fiscal policy can be used as a macroeconomic instrument for economic stability. Intensive government support should be employed as an investment by allocating the funds to productive sectors. In addition, the government needs to make sure that increment in government support does not hurt the economy, particularly the economy of people within the country.
\end{abstract}

Keywords: Government support for Fuel and Wheat, Gregory and Hansen Cointegration, Dynamic Autoregressive-Distributed Lag, Saikonen and Lütkepohl, Zivot-Andrews 


\section{Introduction}

Economic growth is the most dominant instrument for improving personal satisfaction in developing nations. Both cross-country research and nation contextual analyses give intense proof that quick and supported growth is basic to gaining quicker ground towards the Millennium Growth Goals and not simply the principal objective of dividing the worldwide extent of individuals living on under \$1 every day. Growth can create righteous circles of flourishing and opportunity. Solid growth and work openings improve motivating forces for guardians to put resources into their kids' training by sending them to class. This may prompt the rise of a solid and developing gathering of business visionaries, which ought to create pressure for improved administration. Solid economic growth along these lines progresses human growth, which, thus, advances economic growth (McClelland, 2019).

Moreover, Future growth should be founded on an undeniably globalized world that offers new openings yet, in addition, new challenges. New advances offer 'make up for lost time' potential yet additionally 'jumping' conceivable outcomes. New science offers better prospects crosswise over both gainful and administration areas. Also, the government made a decision to buy the Wheat from the farmers at barley higher prices. Interviewed by the Jordan News Agency, Petra, farmers, said that the Cabinet's recent decision to buy their Wheat and barley at JD500 and JD420 per tonne, respectively, would have its "immense" contributions in encouraging the cultivation of the two strategic crops. The prices of imported Wheat and barley stand at JD420 and JD370, respectively, according to Petra. In a recent meeting, the Council of Ministers decided to raise the prices of locally-produced Wheat and barley by JD50 per tonne in a bid to alleviate farmers' burdens and increase the country's production of the two produces. Saleh Raqqad said the decision would support farmers and the agriculture sector, calling on the government to take more steps towards easing off farmers' burdens. For Abdulmahdi Ma'ayah, the decision would encourage farmers to grow more Wheat and barley. The government is expecting to receive less locally-cropped Wheat and barley this year compared with last year, in which it bought 21,300 tonnes from farmers, Petra said. The government has allocated JD15 million to buy around 35,000 tonnes of locally-produced Wheat and barley, according to Petra. While only 1 million dunums of land in Jordan is used to grow Wheat and barley, the country needs 4 million dunums of land to raise these major crops, Petra said. Farmers grow Wheat across the country, but grains are mainly cultivated in Irbid and Houran plains in the north, Madaba and Husban in the central region, and Arrabeh in the southern Governorate of Karak. The Kingdom, which consumes more than 80,000 tonnes of Wheat per month, imports over 96 percent of its wheat needs, as domestic production covers only around 4 percent of demand. Jordan imports the majority of its Wheat from several countries, including Ukraine, Kazakhstan, Russia, Romania, and the United States (IMF Report, 2017).

Moreover, the Jordanian economy did not repeat its strong performance in the 1970s. However, since 1990, performance has become unstable. In addition, the recent growth performance has been weak. The observer of the Jordanian economy notes that it is suffering from worrying conditions in terms of unemployment rates. They are generally high and are a heavy burden on successive governments. As we know, the excellence of government expenditure signifies vital factors of the ineptness of the national budget. The government expenses on the basic need of the country, such as fuel and wheat support, doesn't produce income to decrease the budget 
deficit. The Jordanian government has delivered supports usually to consumers of fuel and Wheat (Al-Fawwaz, 2016).

To protect the people from the current big spikes in global commodities, the Jordanian government supports experienced sharp rises. Jordanian government was paying beyond Jordanian $\$ 600$ million on food and fuel supports, which is about 17 percent of total government expenditures in 2005. Whereas the extent of the supports rose and fell with international price changes, they sustained a challenge for the government. Consumer supports by the government in Jordan has a long history with wheat supports from the year 1960. Maximum food cost was liberalized with the exception of Wheat that has continued to be supported despite occasional attempts at reform by the early 1990s and attempting to remove the wheat support by the government, triggered in extensive social dissatisfaction and vented bread riots in 1996 due to prices trebling of Wheat from JD 0.075 per $\mathrm{kg}$ to JD 0.25 per $\mathrm{Kg}$. Since then, the focus on what support is given relative importance by the Jordanian government (Al-Fawwaz, 2016).

Additionally, at lower market prices, Iraq sales fuel to Jordan before the year 2003. Hence, the Jordanian government handed on these savings to consumers. Whereas, after the year 2003, the source of cheap Jordanian fuel has absented, and this concurred with rises fuel prices globally (World Bank Report, 2009).

From 2002 to 2008, world energy prices rose by three times, whereas global food prices rose double. Jordanian government was obligated to raise fuel prices in 2005 and 2006. However, fuel prices level still kept below international levels. Thus, government expenditure on fuel support reached 5.8\% of GDP in 2005 (Coady et al., 2006).

According to World Bank Report (2015), in the confront of acute fiscal stress, the Jordanian government stopped cash support on fuel products from 2008 to 2010, and hence fuel prices matched the first time with the international level. As a cause of the rapid drop-in fuel support ensued $2.5 \%$ of GDP in 2007 to $0.3 \%$ in 2009. At this point, the Jordanian government compensated households through salary enhancement for private and public sector employees. However, in the latter part of 2010, the monthly fuel price adjustment is discontinued by the Jordanian government since fuel prices touched US\$90 a barrel, and hence, fuel support introduces again. By 2012, fuel support was at 2.8 percent of Jordanian GDP. As a result of facing fiscal pressure, the government again raised the price of fuel by about 13 percent in 2012 June, which headed to the key changes in 2012 November, when support on fuel was cut radically, and a general cash transfer program was instituted. Moreover, there is a lack of empirical studies that analyzed the effect of the government support for fuel and Wheat on economic growth in Jordan. Therefore, it necessitates studying and analyzing it to contribute to the body of knowledge.

\section{Literature Review}

In the course of recent decades, empirical analysis has dedicated expanding thoughtfulness regarding the budget deficit, taxes, interest rate, government support, and economic growth. Regardless of whether fares advance or are unbiased for economic growth is key to the discussion about their relationship. In any case, regardless of huge research, experimental outcomes stay blended and uncertain, making it difficult to summarise the relationship. Al-Shatti (2014) found that public expenditure had a direct impact on economic growth in Jordan during the period between 1993 and 2013. The study further revealed that current expenses and capital expenditure enhances economic growth in Jordan especially. Chinweoke et al. (2014) evaluated 
the association between government expenditure and economic growth in Nigeria through the period between1992-2011.

The study revealed that there was a positive impact of the federal government support on economic growth in Nigeria; however, this impact was insignificant. Olulu et al. (2014) examined the association between government support and economic growth in Nigeria through the period between 1980 and 2010. The study revealed that there was an inverse association between government support and economic growth in Nigeria. The study asserted that government expenditure could help to increase foreign and local investments. Torruam et al. (2014) discovered that government support has a significant contribution to economic growth and development, and therefore government in Nigeria must pay critical attention to public expenditure to make sure that budgets meet the expected expenses to achieve value for money hence enhancing the economy. Abu-Eideh (2015) assessed the causal relationship between government support and the GDP growth in Palestine during the period between 1994 and 2013. The study discovered that government support has a significant positive association with economic growth hence the need for the government to deploy measures and systems to help increase economic activities. The study also found that expenditure and GDP had a significant association with each other. Gemmell et al. (2016) determined the association between GDP and changes in total government supports for a sample of OECD countries through the period betweeni1970 andi2011. The study revealed that these variables had a significant positive impact on economic growth in Nigeria. Novikov et al. (2018) State support for development is considered for the case of examination into the commercialization of new assembling items. Existing models for the help and incitement of advancements are displayed, and the improvement of state programs equipped for animating send-out extensions based on developments in the mechanical building is proposed. Saberi and Hamdan (2019) inspected the degree to which administrations of the Gulf Cooperation Council (GCC) nations assume a directing job in the connection between business enterprise and monetary development. The investigation utilizes a 10-year time arrangement (2006-2015) for six GCC nations: Bahrain, Kuwait, Oman, Qatar, Saudi Arabia, and the United Arab Emirates. Auxiliary wellsprings of information were gathered from The World Bank database, generally accessible measurements on the GCC, the Global Entrepreneurship Index from the Global Entrepreneurship and Development Institute (GEDI), and the Global Entrepreneurship Monitor (GEM) database. Results demonstrate that administrative help has a noteworthy directing impact on the connection among enterprise and monetary development in the GCC. Moreover, the most grounded pointers of pioneering interests in the Gulf have been seen as hazard capital and high development, which demonstrate a quick development in innovative ventures. The most reduced scoring markers were seen as innovation ingestion and advancement process. Regardless of the vital estimates taken to guarantee standard results, for example, testing information legitimacy, care ought to be taken when summing up the examination results chiefly in light of the fact that the time arrangement of the investigation (2006-2015) could have been influenced by the International and Financial Crisis; however, the investigation has contemplated this. 


\section{Methods}

\section{Data Sources and Model Specification}

This investigation pursues the neo-traditional upgraded Solow growth model. Consider the accompanying the Cobb-Douglas development model as pursues:

$$
Q_{t}=C_{t}^{\varphi}\left(R_{t} L F_{t}\right)^{1-m}
$$

Where, $Q_{t}$ is the output, $C_{t}$ is the capital $L F_{t}$ is the labor force; meanwhile, $R_{t}$ Is the level of technology and efficiency, time is denoted by t. Ang (2008), Sharma (2010), Menyah and WoldeRufael (2010), and Shahbaz et al. (2012), among others, include the government support variables in their empirical model to examine the effect on economic growth. While they generally find that government support stimulates economic growth. Hence, the current study extends the equation (1) above by including government support for fuel and Wheat and trade openness and the 2015 Food Crisis.

$$
L N R G D P_{t}=f\left(L N G S W_{t}, L N G S F_{t}, L N T O_{t}, T B_{2015}\right)
$$

This study will transform all the variables into natural logarithms to capture their elasticity value and set them free from the problem of heteroscedasticity. In the empirical version of the model and the econometric analysis, the functional equation is as follow:

$$
L N R G D P_{t}=\theta_{0}+T B_{2015}+\vartheta_{1} L N G S W_{t}+\vartheta_{2} L N G S F_{t}+\vartheta_{3} L N T O P_{t}+\varepsilon_{t}
$$

Where $L N R G D P_{t}$ indicated the natural logarithms of real gross domestic product, $L N G S W_{t}$ indicated the natural logarithms of government support for Wheat, $L N G S F_{t}$ indicated the natural logarithms of government support for fuel; $L N T O_{t}$ indicated the natural logarithms of trade openness and $\varepsilon_{t}$ Is the random error term which is assumed to have a normal distribution with zero mean and predictable variance.

\section{Estimation Procedure}

Based on the previous discussions on government support for fuel and Wheat and trade openness on economic growth in Jordan, the objective of this paper is to reveal the sources of data and set up a model framework suitable for the relationship between the concerned variables. The section shows how various methods will be employed to investigate the effect of government support for fuel and Wheat and trade openness on economic growth in Jordan for the period 1970-2019.

\section{Unit Root Test}

The initial phase in the analysis includes analysing the stationarity property of the data. A procedure is said to be in a unit root structure if its mean and variance are independent of time. To dodge a bias parameter or spurious regression, a unit root test is conducted. The Augmented Dickey-fuller (ADF), Philip-Perron tests (PP), Saikonen and Lütkepohl (SL), and Zivot Andrews (ZA) are utilized to test whether the data have a unit root or not. 


\section{The Augmented Dickey-fuller Unit Root Test}

Augmented Dickey-fuller (1984) expand the basic autoregressive unit root test to suit in general ARMA $(g, r)$ models with baffling orders, and their test is indicated as the ADF test. The test is alluded to as the enlarged Dickey-Fuller (ADF) test. The model gives that the slack length in autorelapse increment with the sample size, $T$, at a controlled rate less than $T .{ }^{1 / 3}$ The basics equation for the model is as follows:

$$
\begin{aligned}
& Q_{t}=\beta_{0} R_{t}+\propto Q_{t-1}+\tau_{t} \\
& \propto(V) U_{t}=\theta(V) \varepsilon t, \varepsilon t \sim M Z(0, \sigma 2)
\end{aligned}
$$

The null hypothesis of the ADF test is that a time series $y_{t}$ Is I(1) beside the alternative that it is I(0). The null hypothesis of the ADF t-test is:

$H_{O}: \theta=0$ while, the alternative hypothesis of

$H_{O}: \theta=0$

This is the assumption that the subtleties in the data have an ARMA configuration. The ADF test is founded on assessing the test regression

$$
N_{t}=\gamma^{\prime} S_{t}+\propto N_{t-1}+\sum_{j=1}^{p} \delta_{j} \Delta N_{t-j}+\rho_{t} u_{t}
$$

Where $D_{t}$ is the deterministic term and $\Delta y_{t-j}$ capture the serial correlation

The ADF t-statistic and normalized bias statistic are

$$
A D F_{t}=l_{\propto=1}=\frac{\widehat{\propto}-1}{S E(\propto)}
$$

$A D F_{t}$, has asymptotic distributions of $t_{\varphi}=1$ under white noise errors provided $\mathrm{p}$ is selected appropriately.

\section{Philip Perron (PP) Unit Root Test}

Phillips and Perron (1988) have dependent on a more grounded exhaustive speculation of unit root non-stationary. The examinations are related to ADF tests. The Phillips-Perron (PP) unit root assessments move from the ADF examinations fundamentally by the manner in which they handle heteroscedasticity and consecutive relationship in the bungles. In point by point, where the ADF assessments apply a parametric auto-regression to measure the ARMA structure of the mix-ups in the examination backslide, the PP tests dismiss any successive relationship in the analysis regression. Consider a model

$$
N_{t}=\theta_{o}+N_{t-1}+\propto_{t}
$$

DF: at $\sim$ iid

PP: at serially-correlated

PP test equation: $N_{t}=\theta_{o}+N_{t-1}+\propto_{t}$

Adding the correction indicators to the DF test statistic, the equation will be:

\section{Saikonen and Lütkepohl}

$$
\begin{aligned}
& H_{0}: \delta=0 \\
& H_{1}: \delta<0
\end{aligned}
$$

Before we begin with empirical analysis, this study will face the stationarity analysis; as such, we employed Saikonen and Lütkepohl (SL) structural break test to examine the stationarity issue. SL 
unit root test provided a solution when shift prevail in the time series, and it is superior over the widely used Augmented Dickey-Fuller (ADF), Phillip-Perron (PP), DF-GLS, and other traditional approaches to unit root tests since they may lead to inefficient and bias results when there is a level shift in the series (Shahbaz, 2013). Therefore, following Saikonen and Lütkepohl (2002) and Lanne et al. (2002) to carry out the unit root test, the empirical modeling is as follows:

$$
y_{t}=\mu_{o}+\mu_{1} t+f_{t}(\theta)^{\prime} \gamma+x_{t}
$$

Where, $f_{t}(\theta)^{\prime} \gamma$ is considered as a shift function, $\theta$ and $\gamma$ are unknown parameter vectors while the errors $x_{t}$ Are generated via the $A R(p)$ process with a possibility of a unit root. A simple dummy variable with shift date $T B_{S A P}$ Is used based on an exponential distribution function. Thus,

$$
f_{t}=d_{1 t}:=\left\{0,1, t<\geq T B_{1997 \& 2015} T B_{1997 \& 2015}\right.
$$

There is no extra parameter $\theta$ involved in the function while $\gamma$ is a scalar in the shift term, $f_{t} \gamma$.

\section{Zivot-Andrews (ZA) Unit Root Test}

The different unit attaches utilized to test the stationary properties of time game plan data, specifically: ADF tests set up by Dickey Fuller (1979), PP tests set up by Philips and Perron (1988), Kwiatkowski-Phillips-Schmidt-Shin (KPSS) tests set up by Kwiatkowski et al. (1992), Dickey-Fuller GLS (DF-GLS) tests set up by Elliott et al. (1996), and Ng-Perron developed by Ng-Perron (2001). All of the tests have a ton of need due to not having information about assistant breakpoints that may happen in the course of action. This prompts beguiling and uneven outcomes. In like way, Zivot-Andrews (1992) set up three models to test the stationarity properties of the segments with the closeness of a fundamental breakpoint in the arrangement. The models as the conditions as pursues:

Equation (12) permits a one-time charge in the limit of the pattern part, which is the slant.

Equation (13) has a one-time change both in pattern and captures elements of the elements to be used for exploratory purposes. Equation (14) allows a one-time change in factors at the level edge. Zivot-Andrews (1992) looked for after three models to check the speculation of a one-time auxiliary break in the arrangement.

$$
\begin{aligned}
& \Delta \varphi_{t}=\vartheta+\vartheta \sigma_{t-1}+\gamma_{t}+\pi \Delta \delta_{t}+\sum_{j=i}^{q} d_{j} \Delta \sigma_{t-j}+\tau_{t} \\
& \Delta z_{t}=\gamma+\gamma \sigma_{t-1}+\pi_{t}+\gamma \Delta T+\sum_{j=i}^{q} d_{j} \Delta \sigma_{t-j}+\tau_{t} \\
& \Delta \varphi_{t}=\pi+\pi \sigma_{t-1}+\omega_{t}+d \Delta \forall_{t}+d \Delta T_{t}+\sum_{j=i}^{q} d_{j} \Delta \sigma_{t-j}+\tau_{t}
\end{aligned}
$$

The dummy indicators are specified by $\Delta \forall_{t}$ presenting mean shift arisen at separately point with time break but trend shift indicators are presented by $\Delta \mathrm{Q}_{\mathrm{t}}$ so,

$$
\begin{array}{ccc}
\Delta \varphi_{t}=f(x)=\{1 & \text { if } q>Q B 0 \quad \text { if } q<Q B\} \\
\text { And } \Delta \varphi_{t}=\{q-Q B \quad \text { if } q>Q B 0 & \text { if } q<Q B\}
\end{array}
$$




\section{Cointegration Test}

In terms of examining the long-run relationship between the variables, the cointegration analysis was utilized. This study used Gregory and Hansen (1996) Cointegration to determine the longrun effect among the independent variables and dependent variable

\section{Gregory and Hansen (1996) Cointegration}

Gregory and Hansen (1996) created a cointegration residual-based technique. This cointegration is assumed to be non-informative, looking at the break timing. Gregory and Hansen (1996) outlined three optional models such as level shift, level shift with the trend, and regime shift. The beauty of these tests is that a researcher may like to test for cointegration over a period of time; while doing that, there may be a break which the timing might not be known to the researcher. This can be treated as an unknown break which the technique will give the exact timing of the break. This method is an extension of Eagle and Granger (1987) test that comprises of estimating the null hypothesis of no cointegration, while an alternate hypothesis of cointegration presence with one unknown structural break in a time series data, this is based on the modified usual ADF, $\mathrm{Za}$ and $\mathrm{Zt}$ test mode. However, the decision criteria are to reject the null hypothesis when the absolute value of $\mathrm{Zt}$ statistics is greater than 5 percent critical value; otherwise, $u$ can't reject the null hypothesis.

The following are the three models:

$$
y_{1 t}=\omega_{1}+\omega_{2} Q_{t \pi}+\alpha^{1} y_{2 t}+e_{t} \quad t=1, \ldots \ldots n \text {. }
$$

The following equation accounts for a trend in the data, however restricting a shift change at the level.

$$
y_{1 t}=\omega_{1}+\omega_{2} Q_{t \pi}+\aleph_{t}+\alpha^{1} y_{2 t}+e_{t} \quad t=1, \ldots \ldots n .
$$

The equation below allows for changes in both the intercept and in the slope of the cointegration vector.

$$
y_{1 t}=\omega_{1}+\omega_{2} Q_{t \pi}+\alpha^{1} y_{1 t}+\alpha_{2}^{1} y_{2 t} Q_{t \pi}+e_{t} \quad t=1, \ldots \ldots n .
$$

The following represent the dummy variable that takes care of the structural break

$\emptyset_{t \pi}=\left\{0,1, \frac{t \leq[n \pi]}{t>[n \pi]}\right.$

Where $\pi=(0,1)$ is the corresponding speck of changing the timing, the distance of this timing is normally captured as $(0.15 n, 0.85 n)$. Both one to three models are serially determined, having the speck of the break changing across the interval $\pi=(0,1)$.

\section{Long run and Short-Run Estimation Using Dynamic Autoregressive Distributive Lags}

As opposed to the complexities of existing ARDL models in looking at the impact of short-and since quite a while ago run in complex model determinations, Jordan and Philips (2018) presented a novel unique animated ARDL model equipped for evaluating, invigorating, and naturally plotting expectations of counterfactual change in one regressor on the needy variable while holding different regressors consistent. To apply the dynamic invigorated ARDL procedure, the information arrangement for the model estimation ought to be coordinated of request one and cointegrated, for which the factors in this work meet the prerequisites. The dynamic ARDL mistake amendment calculation used for the models receives 5000 re-enactments of the vector of parameters from a multivariate ordinary dispersion. This examination shows the various types of communication that uncover the different determinants of reasonable employments. The 
ARDL model with dynamic reproductions proposed by Jordan and Philips (2018) adheres to the standard pathway communicated as:

$$
\begin{aligned}
\Delta L N(r)_{t}=\emptyset_{1} & +\rho_{1}(r)_{t-1}+\rho_{1}\left(q_{1}\right)_{t-1}+\cdots \rho_{k}\left(q_{k}\right)_{t-1}+\sum_{t-1}^{w} \tau_{1} \Delta(r)_{t-1} \\
& +\sum_{j=0}^{g} \pi_{i j} \Delta(q)_{t-j}+\ldots+\sum_{j=0}^{g_{k}} \pi_{k j} \Delta\left(q_{k}\right)_{t-j}+\varphi_{1 t}
\end{aligned}
$$

Where an adjustment in the needy variable $(r)$ is an element of the block $\left(\varnothing_{-} 1\right)$, all the free factors at $\mathrm{t}-1$ in levels to a limit of $g$ and gk slacks in their first-contrasts $(\Delta)$ with blunder term ( $\phi \_1 t$ in time t. The ARDL limits testing methodology for a level relationship by Pesaran et al. (2001) is inspected utilizing Kripfganz and Schneider (2018) basic esteems and rough p-values dependent on reaction surface relapses. To dismiss the invalid theory of no level relationship $\left[H_{-} 0=\emptyset \_0+\right.$ $\left.\emptyset \_1+\ldots+\emptyset_{-} K=0\right]$, the F-measurement from the together zero estimation of all parameters on the free factors in level and the slacked ward variable coefficient must be over the upper bound basic qualities [I (1)], combined with factually critical surmised p-values. In view of the exact particular communicated in Eq. (21), the blunder amendment types of the ARDL-limits models are evaluated as:

$$
\begin{aligned}
\Delta L N(R G D P)_{t} & =\emptyset_{1}+\mu_{1} T B_{2015}+\varphi_{1}(R G D P)_{t-1}+\rho_{1} \Delta(G S W)_{t}+\varphi_{2} \Delta(G S W)_{t-1} \\
& +\rho_{2} \Delta(G S F)_{t}+\varphi_{3} \Delta(G S F)_{t-1}+\rho_{3} \Delta(T O)_{t} \\
& +\varphi_{4} \Delta(T O)_{t-1}
\end{aligned}
$$

Where $\Delta$ denotes difference operator, $\emptyset_{0}$ is the intercepts while $\varphi_{1}, \varphi_{2}, \varphi_{3}, \varphi_{4}$, and $\rho_{1}, \rho_{2}$, and $\rho_{3}$ are the short-run coefficients. Residual term is $\mu_{t}$ And it is assumed to be normally, identically, and independently distributed. The time period is denoted by $t$. The optimal lag length will be chosen using Schwarz Information Criterion (SIC). It has the preferred position of powerful execution and computational straightforwardness (Neath et al., 1997). F-test measurement will be applied to look at the hugeness of the coefficients of the slack factors. Researching the presence of the short-run relationship among the markers in the above conditions and is done using limits testing procedure, which is the essential stage in the ARDL co mix system and relies upon the F-test estimation. Each condition merged both the since a long time ago run and short-run parameters. The Joint noteworthiness test, which suggests no cointegration, is given by the null hypothesis $H_{0}: \vartheta_{1}=\vartheta_{2}=\vartheta_{3}=\vartheta_{4}=0$. Therefore, rejecting the null hypothesis, i.e. $H_{1}: \vartheta_{1} \neq \vartheta_{2} \neq \vartheta_{3} \neq \vartheta_{4} \neq 0$ suggests that cointegration exists among the factors. Two breaking points of essential regards are enlisted by Pesaran et al. (2001) for decision manage everything. The lower bound recognizes that all of the markers are I (0), and the upper bound acknowledge they are all I (1). If the figured F-estimation is more critical than the upper essential regard, there is co coordination. However, when the F-measurement is between the two limits of basic qualities, the examinations get uncertain. All in all, when the $F-$ measurement is not exactly the lower basic esteem, it proposes no cointegration. 
INTERNATIONAL JOURNAL OF ACADEMIC RESEARCH ECONOMICS AND MANAGEMENT SCIENCES

Vol. 10, No. 1, 2021, E-ISSN: 2226-3624 C 2021 HRMARS

\section{Results and Discussion}

\section{Descriptive Statistics and Correlation Analysis}

Table 1 presents the descriptive statistics. The average values of LNRGDP, LNGSW, LNGSF, and LNTOP are $2.45 \%, 3.75 \%, 4.33 \%$, and $4.71 \% \%$, respectively.

Table 1 Descriptive Statistics

\begin{tabular}{|l|c|c|c|c|}
\hline & LNRGDP & LNGSF & LNGSW & LNTOP \\
\hline Mean & 2.456 & 4.330 & 3.747 & 4.707 \\
\hline Median & 2.119 & 4.414 & 3.348 & 4.733 \\
\hline Maximum & 5.555 & 6.274 & 5.217 & 4.984 \\
\hline Minimum & 0.442 & 2.939 & 2.351 & 4.021 \\
\hline Std. Dev. & 1.526 & 1.075 & 1.150 & 0.206 \\
\hline Skewness & 0.736 & 0.060 & 0.158 & -1.304 \\
\hline Kurtosis & 2.415 & 1.424 & 1.218 & 4.976 \\
\hline
\end{tabular}

Table 2 shows the correlation analysis. The results reveal that the correlation between LNGSF, LNGSW, and LNRGDP is negatively very weak -0.12 and -0.56 , respectively. Moreover, the correlation between LNTOP and LNRGDP indicates a weak positive correlation.

Table 2 Correlation Analysis

\begin{tabular}{|c|c|c|c|c|}
\hline & LNRGDP & LNGSF & LNGSW & LNTOP \\
\hline LNRGDP & 1.000 & & & \\
\hline & & & & \\
\hline LNGSF & -0.227 & 1.000 & & \\
\hline & $(0.227)$ & & & \\
\hline LNGSW & $-0.565^{*}$ & $0.739 *$ & 1.000 & \\
\hline & $(0.001)$ & $(0.000)$ & & \\
\hline LNTOP & $0.539 *$ & -0.017 & -0.318 & 1.000 \\
\hline & $(0.002)$ & $(0.927)$ & $(0.085)$ & \\
\hline
\end{tabular}

\section{Unit Root Testing}

Unit root tests are conducted in the study to determine whether there are any variables integrated of order two, which are not ideal for Gregory and Hansen's (1996) Co-integration and DARDL estimations. As can be seen from Table 3, the results of unit root tests show that series are non-stationary at levels but become stationary at first differences; they are said to be integrated of the first order, I(1). In this case, it has been concluded that the existence of a cointegration relationship between these series can be tested since the series under consideration are integrated of the same order. 
INTERNATIONAL JOURNAL OF ACADEMIC RESEARCH ECONOMICS AND MANAGEMENT SCIENCES Vol. 10 , No. 1, 2021, E-ISSN: 2226-3624 @ 2021 HRMARS

Table 3 Result of Unit Root Test

\begin{tabular}{|c|c|c|c|c|c|c|c|c|c|c|}
\hline \multirow[b]{2}{*}{$\begin{array}{c}\text { Variabl } \\
\text { es }\end{array}$} & \multicolumn{4}{|c|}{ ZA } & \multicolumn{2}{|c|}{ SL } & \multicolumn{2}{|c|}{ ADF } & \multicolumn{2}{|c|}{ PP } \\
\hline & Level & $\begin{array}{c}\text { Brk } \\
\text { Date }\end{array}$ & $1^{\text {st }}$ Diff & Brk Date. & Level & $\begin{array}{c}1^{\text {st }} \\
\text { Diff }\end{array}$ & Level & $1^{\text {st }}$ Diff & Level & $1^{\text {st }}$ Diff \\
\hline $\begin{array}{c}\text { LNRGD } \\
P\end{array}$ & -3805 & 1980 & $-1638 *$ & 997) & 0.21 & $6.52^{*}$ & & $\begin{array}{c}- \\
11\end{array}$ & -1999 & $1-13,5$ \\
\hline LNGSF & -2.163 & 2003 & $-5.944^{*}$ & 2009 & 1.87 & $\begin{array}{c}11.87 \\
*\end{array}$ & -1.530 & $\begin{array}{c}- \\
4.619 * \\
\end{array}$ & -1.881 & $-4.627^{*}$ \\
\hline $\begin{array}{c}\text { LNGS } \\
W\end{array}$ & -1.571 & 2006 & $-6.425^{*}$ & 2004 & 0.23 & $\begin{array}{c}10.88 \\
*\end{array}$ & -0.634 & $\begin{array}{c}- \\
5.882 *\end{array}$ & -0.524 & $-5.914^{*}$ \\
\hline LNTOP & -1.889 & 1974 & $-5.745^{*}$ & 1986 & 1.78 & $9.76^{*}$ & -4.094 & $\begin{array}{c}- \\
5.308 *\end{array}$ & -2.650 & $-5.345^{*}$ \\
\hline
\end{tabular}

\section{Cointegration Test}

In terms of examining the long-run relationship between the variables, the cointegration analysis was utilized. This study used Gregory and Hansen's (1996) Cointegration to determine the longrun effect among the independent variables and dependent variables. The need for a cointegration test is vital to aid in establishing long-run bound among series. The traditional cointegration test (see Johansen, 1991; Johansen \& Juselius, 1990) fails to account for the structural break(s). Thus, new breeds of cointegration tests are available in the econometrics literature that helps circumvent spurious analysis and help account for the breaks (Gregory \& Hansen, 1996; Westerlund \& Edgerton, 2007). Thus, this study employs Gregory and Hansen's (1996) cointegration test, which accounts for structural breaks. The result presents in Table 4 below. The result shows that there is a cointegration relationship between interest rate, taxes, and economic growth in Jordan with the existence of different breaks at both levels, trend, and regime. This implies that interest rate, taxes, and economic growth have a long-run cointegration relationship. This result is consistent with Al-Shatti (2014), Chinweoke et al. (2014), Olulu et al. (2014), Abu-Eideh (2015), Novikov et al. (2018), Saberi and Hamdan (2019)

Table 4 Gregory and Hansen (1996) cointegration test Result

\begin{tabular}{|c|c|c|}
\hline & T-Statistics & Date \\
\hline Level & & 1989 \\
\hline ADF & $-5.16^{* *}$ & 1990 \\
\hline Zt & $-5.96^{*}$ & 1990 \\
\hline Za & $-49.76^{* *}$ & \\
\hline Trend & & 1989 \\
\hline ADF & $-5.33^{* *}$ & 1990 \\
\hline Zt & $-5.97^{*}$ & 1990 \\
\hline Za & -49.66 & \\
\hline Regime & & 1976 \\
\hline ADF & $-5.79^{* *}$ & 1974 \\
\hline Zt & $-6.65^{*}$ & 1974 \\
\hline Za & $-46.57^{* *}$ & \\
\hline
\end{tabular}




\section{Long-run and Short-run Estimates}

Table 5 represents the Long-run and Short-run results. In the long-run and short-run, coefficients for $L N G S F_{t}, L N G S W_{t}$, and $L N T O_{t}$, are positive and significant at $5 \%$, respectively, while the coefficients for $L N T B_{2015}$ are negative and statistically significant at $5 \%$. However, the short-run coefficient for $L N T O$ is statistically not significant. The signs of all the variables are in line with the theoretical predictions. The results indicated that a $1 \%$ increase in $L N G S F_{t}, L N G S W_{t}$, and $L N T O_{t}$, will lead to a $0.443 \%, 0.678 \%$, and $0.456 \%$ increase in economic growth in the long run. Conversely, A $1 \%$ decrease in the 2015 Food Crisis will lead to a $0.110 \%$ and $0.168 \%$ increase in the economic growth in both the short-run and long-run, respectively. Moreover, the diagnostic test shows that the chi-square values indicated the absence of serial correlation and heteroscedasticity. It also reveals that the model is correctly specified, and the series is normally distributed. Therefore, the results do not reject the null hypothesis for the diagnostic test. The $R^{2}$ value shows that the independent variables explained the dependent variable by $60 \%$.

able 5 Estimates Results

\begin{tabular}{|c|c|c|l|}
\hline \multicolumn{4}{|c|}{ Dependent variable: $L N G D P_{t}$} \\
\hline Variables & \multicolumn{3}{|c|}{ Coefficients } \\
\hline LNGSF $_{t}$ & & $0.443^{* *}$ & \\
\hline$\Delta L N G S F_{t}$ & & $0.315^{* *}$ & \\
\hline LNGSW $_{t}$ & & $0.678^{* *}$ & \\
\hline$\Delta L N S W_{t}$ & & $0.456^{* *}$ & \\
\hline$L N T O_{t}$ & & $0.213^{*}$ & \\
\hline$\Delta L N T O_{t}$ & & -0.123 & \\
\hline$L N T B_{2015}$ & & $-0.110^{*}$ & \\
\hline$\Delta L N T B_{2015}$ & & $-0.168^{*}$ & \\
\hline & & & \\
\hline$R^{2}$ & 0.60 & & \\
\hline Adj-R & 0.46 & & \\
\hline F-Statistics & $8.431(0.000)$ & & \\
\hline$\gamma_{\text {ser }}$ & $0.324(0.829)$ & & \\
\hline$\gamma_{\text {Hetr }}$ & $0.567(0.782)$ & & \\
\hline$\gamma_{\text {Nor }}$ & $0.156(0.488)$ & & \\
\hline
\end{tabular}

\section{Discussion and Conclusion}

The main objective of this paper has been to explore the effect of government support on economic growth in Jordan, which is measured as the growth rate of real GDP. While focusing on two government support categories, namely fuel, and Wheat. This paper employed Gregory and Hansen's (1996) Co-integration and DARDL estimations in order to find the fixed effects of government support on economic growth. We used time-series data for Jordan over the period of $1970-2019$. The result shows that larger government support may lead to higher economic growth. Moreover, as we classify the government support into some categories, expenditure, namely fuel and Wheat, significantly lead to higher economic growth. In other words, the evidence indicated that the growth rate of real GDP is enhanced by government support for fuel and Wheat. Given the positive relationship between the government support for fuel and Wheat 
and economic growth, as what has been suggested by Wagner's law. The government is suggested to use the government support in a better way and un-excessively. If government support is utilized in the excess amount, the excessive development support becomes unproductive at the margin. Moreover, fiscal policy can be used as a macroeconomic instrument for economic stability. Intensive government support should be employed as an investment by allocating the funds to productive sectors. In addition, the government needs to make sure that increment in government support does not hurt the economy, particularly the economy of people within the country. If increment in government support will lead to higher tax costs or higher borrowing, which result in higher interest payable, government support might not achieve its purpose of accelerating economic growth. However, this study has a limitation, which it does not include the causality test to find out the direction of causality between these two variables. Future research may look into this area to analyze which variable affect the other variable, or is there any evidence of bi-directional causality between government support for fuel and Wheat and economic growth. This test may give us a much more proper policy implication in designing the fiscal policy for the future economy.

\section{References}

Abu-Eideh, O. M. (2015). Causality between public expenditure and GDP growth in Palestine: An econometric analysis of Wagner's law. Journal of Economics and Sustainable Development, 6(2), 189-199.

Al-Fawwaz, T. M. (2016). The impact of government expenditures on economic growth in Jordan (1980-2013). International Business Research, 9(1), 99.

Al-Shatti, A. S. (2014). The Impact of Public Expenditures on Economic Growth in

Ang, J. B. (2008). What are the mechanisms linking financial development and economic growth in Malaysia?. Economic Modelling, 25(1), 38-53.

Chinweoke, N., Ray, N., \& Paschal, N. (2014). Impact of government expenditure on Nigeria's economic growth (1992-2011). The Macro theme Review: A Multidisciplinary Journal of Global Macro Trends, 3(7), 79-87.

Coady, D. P., El Said, M., Gillingham, R., Kpodar, K., Medas, P. A., \& Newhouse, D. L. (2006). The magnitude and distribution of fuel subsidies: evidence from Bolivia, Ghana, Jordan, Mali, and Sri Lanka.

Dickey, D. A., \& Fuller, W. A. (1979). Distribution of the estimators for autoregressive time series with a unit root. Journal of the American statistical association, 74(366a), 427-431.

Dickey, D. A., Hasza, D. P., \& Fuller, W. A. (1984). Testing for unit roots in seasonal time series. Journal of the American Statistical Association, 79(386), 355-367.

Eagle, D., \& Stephanedes, Y. J. (1987). Dynamic highway impacts on economic development. Transportation $R$

Elliott, G., Rothenberg, T. J., \& Stock, J. H. (1996). Efficient Tests for an Autoregressive Unit Root. Econometrics 64 (4): 813-836.

Gemmell, N., Kneller, R., \& Sanz, I. (2016). Does the Composition of Government Expenditure Matter for Long-Run GDP Levels? Oxford Bulletin of Economics and Statistics, 78(4), 522547. 
Gregory, A. W., \& Hansen, B. E. (1996). Practitioners corner: tests for cointegration in models with the regime and trend shifts. Oxford Bulletin of Economics and Statistics, 58(3), 555560.

Kwiatkowski, D., Phillips, P. C., Schmidt, P., \& Shin, Y. (1992). Testing the null hypothesis of stationarity against the alternative of a unit root: How sure are we that economic time series have a unit root? Journal of econometrics, 54(1-3), 159-178.

Lanne, M., Lütkepohl, H., \& Saikkonen, P. (2002). Comparison of unit root tests for time series with level shifts. Journal of time series analysis, 23(6), 667-685.

McClelland, D. C. (2019). The achievement motive in economic growth. In The Gap Between Rich and Poor (pp. 53-69). Routledge.

Menyah, K., \& Wolde-Rufael, Y. (2010). CO2 emissions, nuclear energy, renewable energy, and economic growth in the US. Energy Policy, 38(6), 2911-2915.

Ng, S., \& Perron, P. (2001). Lag length selection and the construction of unit root tests with good size and power. Econometrica, 69(6), 1519-1554.

Olulu, R. M., Erhieyovwe, E. K., \& Andrew, U. (2014). Government expenditures and economic growth: The Nigerian Experience. Mediterranean Journal of social sciences, 5(10), 89.

Phillips, P. C., \& Perron, P. (1988). Testing for a unit root in time series regression. Biometrika, 75(2), 335-346.

Saberi, M., \& Hamdan, A. (2019). The moderating role of governmental support in the relationship between entrepreneurship and economic growth: A study on the GCC countries. Journal of Entrepreneurship in Emerging Economies, 11(2), 200-216.

Shahbaz, M., Zeshan, M., \& Afza, T. (2012). Is energy consumption effective in spurring economic growth in Pakistan? New evidence from bounds test to level relationships and Granger causality tests. Economic Modelling, 29(6), 2310-2319.

Sharma, S. S. (2010). The relationship between energy and economic growth: empirical evidence from 66 countries. Applied Energy, 87(11), 3565-3574.

Torruam, J. T., Chiawa, M. A., \& Abur, C. C. (2014). Cointegration Analysis of Public Expenditure on Tertiary Education and Economic Growth in Nigeria. CBN Journal of Applied Statistics, 5(2), 137-146.

World Bank. (2009) https://databank.worldbank.org/source/world-development-indicators: Accessed on December 2009.

Zaitseva, O. P., Kozlova, O. A., Blinov, O. A., Novikov, Y. I., \& Golova, E. E. (2018). The Potential Volume of Government Support for a Regionâ€ $€^{\mathrm{TM}}$ s Agricultural Sector in a Climate of Import Substitution. The Journal of Social Sciences Research, 392-399. 